\title{
Effect of invitro Rooting in Coccinia grandis (L.) through Nodal Segments
}

\author{
Mohammad Amin ${ }^{1 *}$, A. V. D. Dorajee Rao ${ }^{2}$, K. Ravindra Kumar ${ }^{2}$ \\ and D. R. Salomi suneetha ${ }^{3}$ \\ ${ }^{1}$ Department of Vegetable Science, ${ }^{2}$ Department of Horticulture, ${ }^{3}$ Department of \\ Biochemistry, College of Horticulture, Dr.Y.S.R Horticultural University, \\ Venkataramannagudem, West Godavari, India \\ *Corresponding author
}

\section{A B S T R A C T}

\section{Keywords}

In vitro rooting, coccinia, Nodal segments

\section{Article Info}

Accepted:

20 June 2020

Available Online:

10 July 2020

\begin{abstract}
An experiment was conducted on in vitro rooting in Coccinia grandis (L.) through nodal segments with an objective to standardise a viable protocol for in vitro propagation. Maximum number of shoots producing roots was noticed in $1 / 2 \mathrm{MS}+0.5 \mathrm{mg} \mathrm{l}^{-1}$ IBA which was on par with $1 / 2 \mathrm{MS}+1.0 \mathrm{mg} \mathrm{l}^{-1}$ IBA and $1 / 2 \mathrm{MS}+0.5 \mathrm{mg} \mathrm{l}^{-1} \mathrm{NAA}$. The maximum number of roots per shoot (6.00) was observed by $1 / 2 \mathrm{MS}+1.0 \mathrm{mg} \mathrm{l}^{-1}$ IBA $\left(\mathrm{T}_{2}\right)$ and $1 / 2 \mathrm{MS}$ medium devoid of any growth regulators as control. The maximum girth of longest root was recorded by $1 / 2 \mathrm{MS}+0.5 \mathrm{mg} \mathrm{l}^{-1}$ IBA which was on par with $1 / 2 \mathrm{MS}+0.5 \mathrm{mg} \mathrm{l}^{-1}$ NAA but significantly superior to the MS $+1.0 \mathrm{mg} \mathrm{l}^{-1} \mathrm{NAA}$. The root colour was observed as white in $1 / 2 \mathrm{MS}+0.5 \mathrm{mg} \mathrm{l}^{-1} \mathrm{IBA}\left(\mathrm{T}_{1}\right), 1 / 2 \mathrm{MS}+1.0 \mathrm{mg} \mathrm{l}^{-1} \mathrm{IBA}\left(\mathrm{T}_{2}\right)$ and $1 / 2 \mathrm{MS}$ medium devoid of any growth regulators as control whereas pale white colour root was observed in the rest of treatments.
\end{abstract}

\section{Introduction}

Coccinia grandis $\mathrm{L}$. belongs to the family Cucurbitaceae and is described as 'Indian substitute for Insulin". It grows widely throughout India and other tropical countries but it is commonly found in the southern Indian states, where it forms a part of the local cuisine. Ivy gourd has been extensively used in ayurvedic and unani practices in the Indian Subcontinent. It contains several phytoconstituents such as cephalandrol, iritriacontane, Triterpenoids, alkaloids and tannins. The plant also possesses hypoglycemic effects and acts as insulin mimetic (Thiripurasundari and Rao, 2012).
General barriers like poor seed setting and low seed germination is a common in Cucurbits including Coccinea, probably due to the presence of a thin nucellar membrane lending impermeability to water and gases making them dormant for many days (Thiripurasundari and Rao, 2012). The use of tissue culture techniques for clonal propagation has become the most widely used application of tissue culture technology in horticultural crops in the recent years (Thorpe, 1990). In vitro propagation can effectively escape from these problems and as such micro propagated material are reported to grow faster and mature earlier than seed propagated ones (Vasil and Vasil, 1980). The 
present investigation is undertaken with a view to standardise the techniques of surface sterilisation, aimed at developing a viable protocol for propagation of coccinea through in vitro procedures.

\section{Materials and Methods}

An investigation was carried out at Tissue Culture Laboratory, Horticultural Research station, Kovvur, College of Horticulture, Dr. Y. S. R. Horticultural University, Venkataramannagudem, Andhra Pradesh, during the year 2019-2020.

\section{Plant material}

Nodal segments of ivy gourd were involved in the present study. Nodal segments (two $\mathrm{cm}$ long) were collected from young vines maintained in the propagation chamber at the HRS, Kovvur and were used for the preparation of explants.

To find out the best in vitro rooting media, the nodal segments were pre-treated with the best treatment of Carbandazim (0.2\%) + Mancozeb \& Metalaxyl $(0.2 \%)+200$ ppm 8 HQ for $60 \mathrm{~min}$, then explants sterilized with best treatment of $0.1 \% \mathrm{HgCl}_{2}$ for 4 minutes and the better culture establishment was effectively induced by TDZ at $0.5 \mathrm{mg}^{-1}$ concentration for shoot induction and succeeding growth in the present study.

\section{Results and Discussion}

\section{In vitro rooting}

The third experiment was conducted on standardisation of different growth regulator concentrations for in vitro rooting. The results for number of shoots producing roots, rooting percent, number of roots per shoot and length of longest root after 20 days of culture are described hereunder

\section{Number of shoots producing roots}

The treatments varied significantly in terms of number of shoots producing roots. The mean number of shoots producing roots was 7.61 (Table 3.1). The maximum number of shoots producing roots was noticed in $1 / 2 \mathrm{MS}+0.5$ $\mathrm{mg} \mathrm{l}^{-1}$ IBA $\left(\mathrm{T}_{1}\right)$ (9.50) which was on par with $1 / 2 \mathrm{MS}+1.0 \mathrm{mg} \mathrm{l}^{-1} \mathrm{IBA}\left(\mathrm{T}_{2}\right)(8.75)$ and $1 / 2 \mathrm{MS}$ $+0.5 \mathrm{mg}^{-1} \mathrm{NAA}\left(\mathrm{T}_{3}\right)(8.25)$ but significantly superior to the $1 / 2 \mathrm{MS}+0.5 \mathrm{mg} \mathrm{l}^{-1} \mathrm{NAA}+0.5$ $\mathrm{mg} \mathrm{l}^{-1}$ IBA $\left(\mathrm{T}_{5}\right)$. However, the minimum number of shoots producing roots was (6.25) observed in $1 / 2 \mathrm{MS}+1.0 \mathrm{mg} \mathrm{l}^{-1} \mathrm{NAA}+1.0 \mathrm{mg}$ $1^{-1} \operatorname{IBA}\left(\mathrm{T}_{6}\right)$.

\section{Rooting percentage (\%)}

The rooting percentage exhibited significant differences among the treatments (Table 3.1). The mean rooting per cent was $(76.07 \%)$. The highest rooting per cent was recorded in $1 / 2$ $\mathrm{MS}+0.5 \mathrm{mg} \mathrm{l}^{-1} \mathrm{IBA}\left(\mathrm{T}_{1}\right)(95.00 \%)$ which was on par with $1 / 2 \mathrm{MS}+1.0 \mathrm{mg} \mathrm{l}^{-1}$ IBA $\left(\mathrm{T}_{2}\right)$ $(87.50 \%)$ but significantly superior to the $1 / 2$ $\mathrm{MS}+0.5 \mathrm{mg} \mathrm{l}^{-1} \mathrm{NAA}\left(\mathrm{T}_{3}\right)(82.50 \%)$. However, the least rooting per cent $(62.50 \%)$ was noticed by in $1 / 2 \mathrm{MS}+1.0 \mathrm{mg} \mathrm{l}^{-1} \mathrm{NAA}+$ $1.0 \mathrm{mg} \mathrm{l}^{-1}$ IBA $\left(\mathrm{T}_{6}\right)$ which was on par with $1 / 2$ MS medium devoid of any growth regulators as control $\left(\mathrm{T}_{7}\right)(67.50 \%)$ and $1 / 2 \mathrm{MS}+1.0 \mathrm{mg}$ $\mathrm{I}^{-1} \mathrm{NAA}\left(\mathrm{T}_{4}\right)(65.00 \%)$.

\section{Number of days taken for rooting}

The treatments varied significantly in terms of number of days taken for rooting. The mean number of days taken for rooting was (8.29) (Table 3.1). The minimum number of days taken for rooting was noticed in $1 / 2 \mathrm{MS}+0.5$ $\mathrm{mg}^{-1}$ IBA $\left(\mathrm{T}_{1}\right)$ (6.20) which was on par with $1 / 2 \mathrm{MS}+1.0 \mathrm{mg} \mathrm{l}^{-1} \mathrm{IBA}\left(\mathrm{T}_{2}\right)$ (6.60) and $1 / 2 \mathrm{MS}$ $+0.5 \mathrm{mg} \mathrm{l}^{-1} \mathrm{NAA}\left(\mathrm{T}_{3}\right)(8.25)$ but significantly superior to the $1 / 2 \mathrm{MS}+1.0 \mathrm{mg} \mathrm{l}^{-1} \mathrm{NAA}\left(\mathrm{T}_{4}\right)$. However, the maximum number of days taken for rooting was (11.50) observed in $1 / 2 \mathrm{MS}$ 
medium devoid of any growth regulators as control $\left(\mathrm{T}_{7}\right)(11.50)$.

\section{Number of roots per shoot}

The differences were found to be significant among the treatments with respect to number of roots per shoot. The mean number of roots per shoot was (4.14) (Table 3.2). The maximum number of roots per shoot (6.00) was observed by $1 / 2 \mathrm{MS}+1.0 \mathrm{mg} \mathrm{l}^{-1} \mathrm{IBA}\left(\mathrm{T}_{2}\right)$ and $1 / 2$ MS medium devoid of any growth regulators as control $\left(\mathrm{T}_{7}\right)$.

Table.1 Effect of different auxins on rooting and days taken for rooting during in vitro root induction of coccinea nodal segments

\begin{tabular}{|c|c|c|c|c|}
\hline Treatments & $\begin{array}{l}\text { No. of shoots } \\
\text { cultured }\end{array}$ & $\begin{array}{l}\text { No. of shoots } \\
\text { producing roots }\end{array}$ & $\begin{array}{c}\text { Rooting } \\
(\%)\end{array}$ & $\begin{array}{l}\text { No. of days taken } \\
\text { for rooting }\end{array}$ \\
\hline $\mathrm{T}_{1}: 1 / 2 \mathrm{MS}+0.5 \mathrm{mg} \mathrm{l}^{-1} \mathrm{IBA}$ & 10 & 9.50 & $\begin{array}{l}95.00 \\
(77.05)\end{array}$ & 6.2 \\
\hline $\mathrm{T}_{2}: 1 / 2 \mathrm{MS}+1.0 \mathrm{mg} \mathrm{l}^{-1} \mathrm{IBA}$ & 10 & 8.75 & $\begin{array}{c}87.50 \\
(69.27)\end{array}$ & 6.6 \\
\hline $\mathrm{T}_{3}:{ }^{1 / 2} \mathrm{MS}+0.5 \mathrm{mg} \mathrm{l}^{-1} \mathrm{NAA}$ & 10 & 8.25 & $\begin{array}{c}82.50 \\
(65.24)\end{array}$ & 7.5 \\
\hline $\mathrm{T}_{4}: 1 / 2 \mathrm{MS}+1.0 \mathrm{mg} \mathrm{l}^{-1} \mathrm{NAA}$ & 10 & 6.50 & $\begin{array}{c}65.00 \\
(53.71)\end{array}$ & 8.4 \\
\hline $\mathrm{T}_{5}: 1 / 2 \mathrm{MS}+0.5 \mathrm{mg} \mathrm{l}^{-1} \mathrm{NAA}+0.5 \mathrm{mg} / \mathrm{l} \mathrm{IBA}$ & 10 & 7.25 & $\begin{array}{c}72.50 \\
(58.35)\end{array}$ & 8.8 \\
\hline $\mathrm{T}_{6}: 1 / 2 \mathrm{MS}+1.0 \mathrm{mg} \mathrm{l}^{-1} \mathrm{NAA}+1.0 \mathrm{mg} \mathrm{l}^{-1} \mathrm{IBA}$ & 10 & 6.25 & $\begin{array}{c}62.50 \\
(52.22)\end{array}$ & 9.0 \\
\hline $\begin{aligned} T_{7}: & 1 / 2 \text { MS medium devoid of any growth } \\
& \text { regulators as control }\end{aligned}$ & 10 & 6.75 & $\begin{array}{c}67.50 \\
(55.22)\end{array}$ & 11.5 \\
\hline Mean & 10.00 & 7.61 & $\begin{array}{c}\mathbf{7 6 . 0 7} \\
(61.58)\end{array}$ & 8.29 \\
\hline S Em & & 0.35 & 1.85 & 0.36 \\
\hline CD at 0.01 & & 1.51 & 7.87 & 1.51 \\
\hline CD at 0.05 & & 1.08 & 5.65 & 1.09 \\
\hline
\end{tabular}

Table.2 Effect of different auxins on root parameters during in vitro root induction of coccinea nodal segments

\begin{tabular}{|c|c|c|c|c|}
\hline Treatments & $\begin{array}{l}\text { No. of } \\
\text { roots per } \\
\text { shoot }\end{array}$ & $\begin{array}{l}\text { Length of the } \\
\text { longest root } \\
\text { (cm) }\end{array}$ & $\begin{array}{l}\text { Girth of the } \\
\text { longest root } \\
(\mathbf{m m})\end{array}$ & $\begin{array}{l}\text { Root } \\
\text { colour }\end{array}$ \\
\hline $\mathrm{T}_{1}: 1 / 2 \mathrm{MS}+0.5 \mathrm{mg} \mathrm{l}^{-1} \mathrm{IBA}$ & 5.00 & 4.20 & 0.98 & white \\
\hline $\mathrm{T}_{2}: 1 / 2 \mathrm{MS}+1.0 \mathrm{mg} \mathrm{l}^{-1} \mathrm{IBA}$ & 6.00 & 4.80 & 0.87 & white \\
\hline $\mathrm{T}_{3}: 1 / 2 \mathrm{MS}+0.5 \mathrm{mg} \mathrm{l}^{-1} \mathrm{NAA}$ & 3.00 & 3.80 & 0.92 & white \\
\hline $\mathrm{T}_{4}: 1 / 2 \mathrm{MS}+1.0 \mathrm{mg} \mathrm{l}^{-1} \mathrm{NAA}$ & 4.00 & 3.20 & 0.89 & Pale white \\
\hline $\mathrm{T}_{5}: 1 / 2 \mathrm{MS}+0.5 \mathrm{mg} \mathrm{l}^{-1} \mathrm{NAA}+0.5 \mathrm{mg} \mathrm{l}^{-1} \mathrm{IBA}$ & 2.00 & 3.00 & 0.78 & Pale white \\
\hline$T_{6}: 1 / 2 \mathrm{MS}+1.0 \mathrm{mg} \mathrm{l}^{-1} \mathrm{NAA}+1.0 \mathrm{mg} \mathrm{l}^{-1} \mathrm{IBA}$ & 3.00 & 2.80 & 0.76 & Pale white \\
\hline $\begin{array}{c}\mathrm{T}_{7}: \begin{array}{l}1 / 2 \mathrm{MS} \text { medium devoid of any growth regulators as } \\
\text { control }\end{array}\end{array}$ & 6.00 & 5.30 & 0.36 & white \\
\hline Mean & 4.14 & 3.87 & 0.79 & \\
\hline S Em & 0.31 & 0.19 & 0.04 & \\
\hline CD at 0.01 & 1.34 & 0.81 & 0.18 & \\
\hline CD at 0.05 & 0.96 & 0.58 & 0.13 & \\
\hline
\end{tabular}


Fig.1 In vitro rooting of coccinea nodal segments in vitro as influenced by different growth regulator concentrations
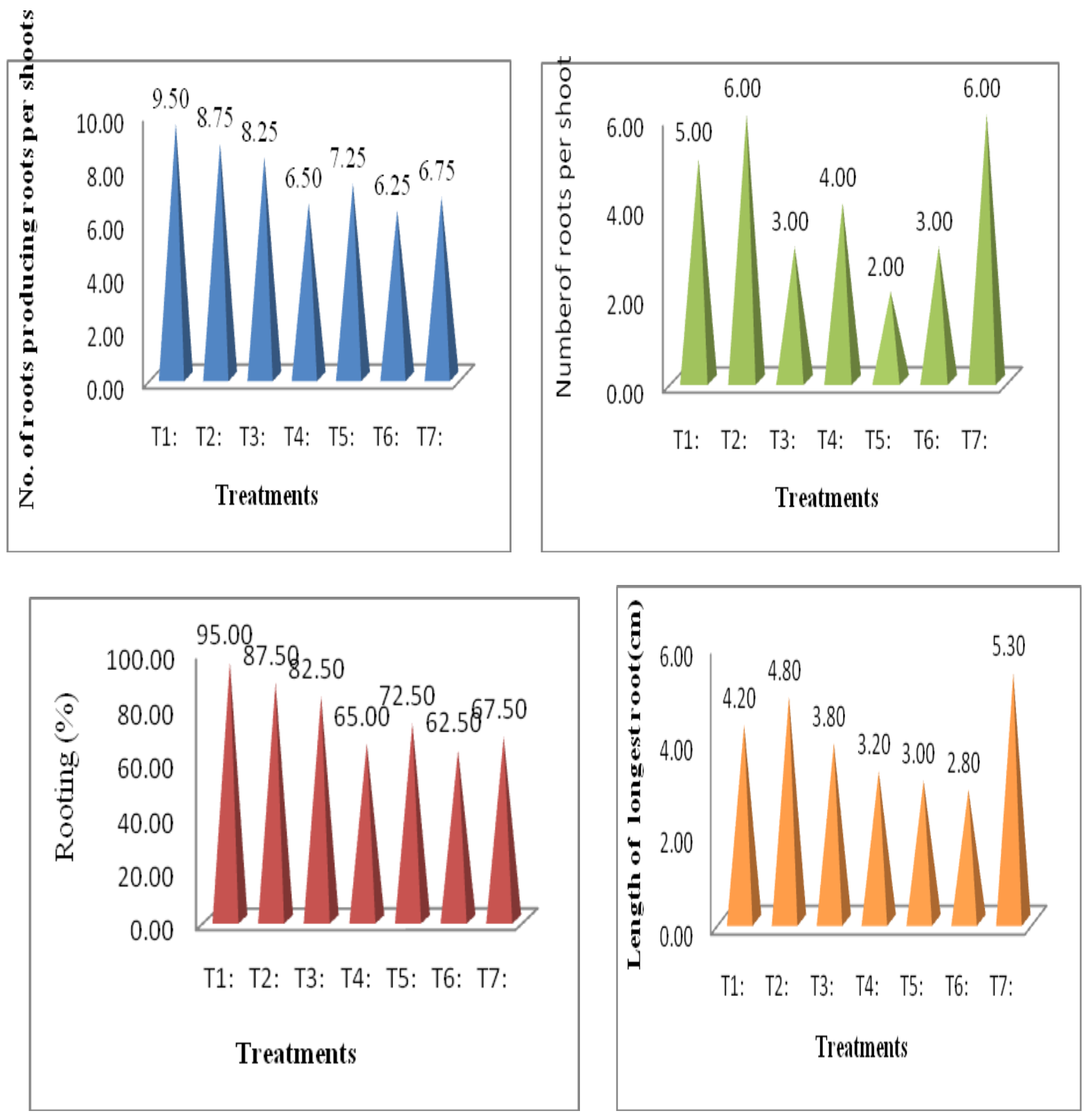

$\mathrm{T}_{1}: \quad 1 / 2 \mathrm{MS}+0.5 \mathrm{mg} \mathrm{l}^{-1} \mathrm{BAP}$

Treatments

$\mathrm{T}_{2}: \quad 1 / 2 \mathrm{MS}+1.0 \mathrm{mg} \mathrm{l}^{-1} \mathrm{BAP}$

$\mathrm{T}_{3}: \quad 1 / 2 \mathrm{MS}+0.5 \mathrm{mg} \mathrm{l}^{-1} \mathrm{NAA}$

$\mathrm{T}_{4}: \quad 1 / 2 \mathrm{MS}+1.0 \mathrm{mg} \mathrm{l}^{-1} \mathrm{NAA}$

$\mathrm{T}_{5}: \quad 1 / 2 \mathrm{MS}+0.5 \mathrm{mg} \mathrm{l}^{-1} \mathrm{BAP}+1.0 \mathrm{mg} \mathrm{l}^{-1} \mathrm{NAA}$

$\mathrm{T}_{6} \quad 1 / 2 \mathrm{MS}+1.0 \mathrm{mg} \mathrm{l}^{-1} \mathrm{BAP}+1.0 \mathrm{mg} \mathrm{l}^{-1} \mathrm{NAA}$

$\mathrm{T}_{7} \quad 1 / 2$ MS medium devoid of any growth regulators as control 
Plate.1 Effect of different auxins on Coccinia micro-shoots in vitro rooting

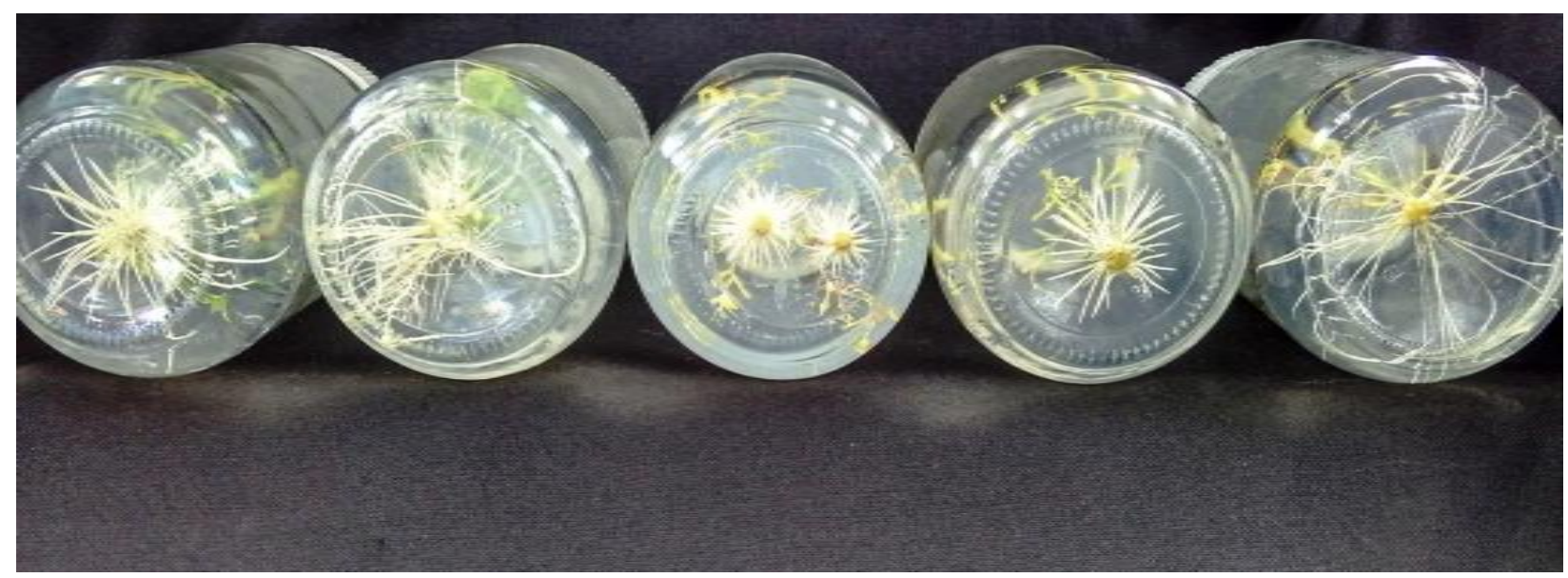

0.5 IBA, 1.0 IBA, 0.5 NAA, 1.0 NAA and Control from left to right

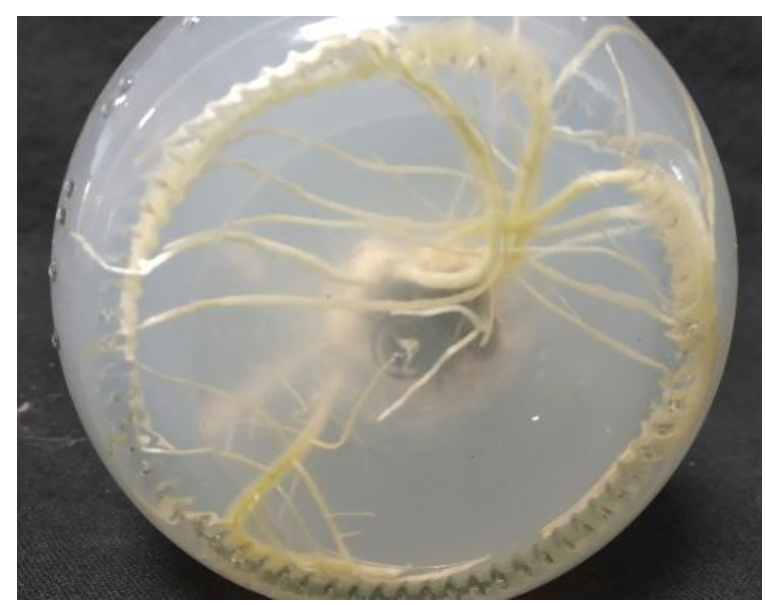

0.5 IBA media (Best treatment)

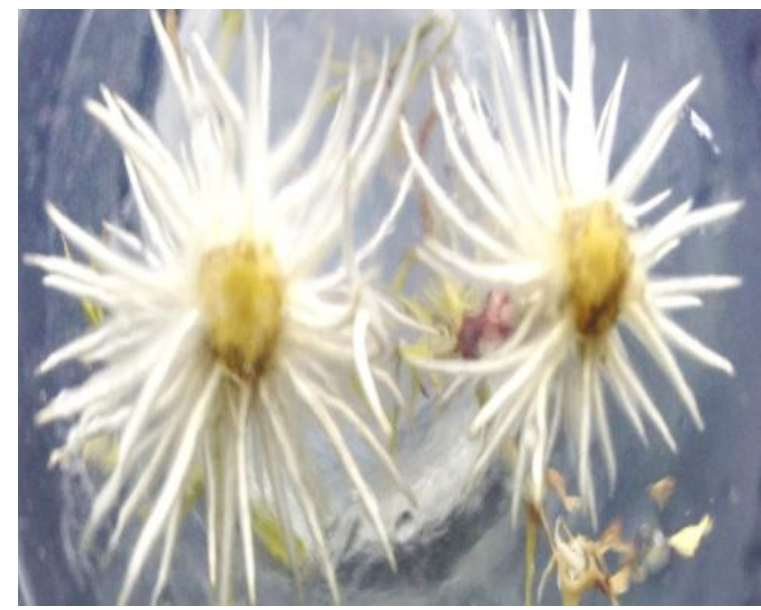

1.0 NAA media

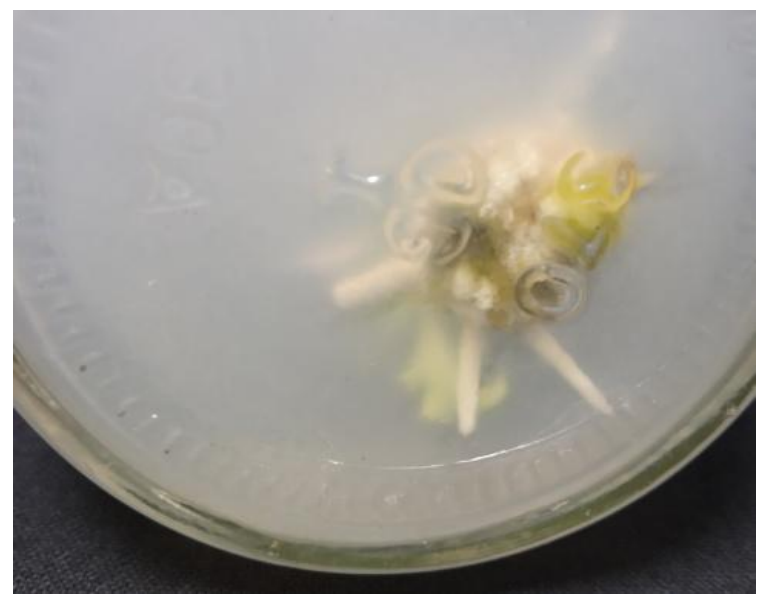

1.0 NAA + 1.0 IBA media

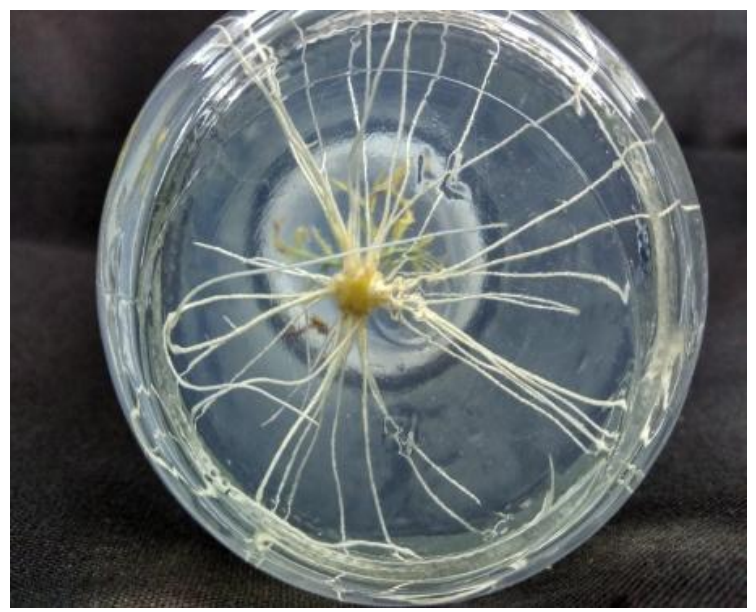

Control 
The minimum number of roots per shoot was (2.00) recorded in $1 / 2 \mathrm{MS}+0.5 \mathrm{mg} \mathrm{l}^{-1} \mathrm{NAA}+$ $0.5 \mathrm{mg} \mathrm{l}^{-1}$ IBA $\left(\mathrm{T}_{5}\right)$.

\section{Length of longest root $(\mathrm{cm})$}

Significant differences were exhibited for length of longest root among the treatments (Table 3.2). The mean length of longest root was $(3.87 \mathrm{~cm})$. The maximum length of longest root was recorded by $1 / 2 \mathrm{MS}$ medium devoid of any growth regulators as control $\left(\mathrm{T}_{7}\right)(5.30 \mathrm{~cm})$ which was on par with $1 / 2 \mathrm{MS}+$ $1.0 \mathrm{mg} \mathrm{l}^{-1} \mathrm{IBA}\left(\mathrm{T}_{2}\right)(4.80 \mathrm{~cm})$ and $1 / 2 \mathrm{MS}+0.5$ $\mathrm{mg} \mathrm{l}^{-1}$ IBA $\left(\mathrm{T}_{1}\right)(4.20 \mathrm{~cm})$. However, The minimum length of longest root was $(2.80$ $\mathrm{cm}$ ) observed in $1 / 2 \mathrm{MS}+1.0 \mathrm{mg} / \mathrm{l} \mathrm{NAA}+1.0$ $\mathrm{mg} \mathrm{l}^{-1} \mathrm{IBA}\left(\mathrm{T}_{6}\right)$.

\section{Girth of the longest root (mm)}

Significant differences were exhibited for girth of the longest root among the treatments (Table 3.2). The mean girth of the longest root was $(0.79 \mathrm{~mm})$. The maximum girth of longest root was recorded by $1 / 2 \mathrm{MS}+0.5 \mathrm{mg}$ $\mathrm{l}^{-1}$ IBA $\left(\mathrm{T}_{1}\right)(0.98 \mathrm{~mm})$ which was on par with $1 / 2 \mathrm{MS}+0.5 \mathrm{mg} \mathrm{l}^{-1} \mathrm{NAA}\left(\mathrm{T}_{3}\right)$ but significantly superior to the $\mathrm{MS}+1.0 \mathrm{mg} \mathrm{l}^{-1} \mathrm{NAA}\left(\mathrm{T}_{4}\right)$. However, the minimum girth of longest root was $(0.36 \mathrm{~mm})$ observed in $1 / 2 \mathrm{MS}$ medium devoid of any growth regulators as control $\left(\mathrm{T}_{7}\right)$.

\section{Root colour}

Significant differences were exhibited for root colour among the treatments (Table 3.2). The root colour was observed as white in $1 / 2 \mathrm{MS}+$ $0.5 \mathrm{mg} \mathrm{l}^{-1} \mathrm{IBA}\left(\mathrm{T}_{1}\right), 1 / 2 \mathrm{MS}+1.0 \mathrm{mg} \mathrm{l}^{-1} \mathrm{IBA}$ $\left(\mathrm{T}_{2}\right)$ and $1 / 2 \mathrm{MS}$ medium devoid of any growth regulators as control $\left(\mathrm{T}_{7}\right)$ whereas pale white colour root was observed in $1 / 2 \mathrm{MS}+0.5 \mathrm{mg} \mathrm{l}^{-1}$ $\mathrm{NAA}\left(\mathrm{T}_{3}\right), \mathrm{MS}+1.0 \mathrm{mg} \mathrm{l}^{-1} \mathrm{NAA}\left(\mathrm{T}_{4}\right), 1 / 2 \mathrm{MS}+$ $0.5 \mathrm{mg} \mathrm{l}^{-1} \mathrm{NAA}+0.5 \mathrm{mg} \mathrm{l}^{-1} \mathrm{IBA}\left(\mathrm{T}_{6}\right)$ and $1 / 2$ $\mathrm{MS}+1.0 \mathrm{mg} / \mathrm{l} \mathrm{NAA}+1.0 \mathrm{mg} \mathrm{l}^{-1} \mathrm{IBA}\left(\mathrm{T}_{6}\right)$.
Induction of roots from callus is one of the most critical steps for in vitro propagation of plants. This brings qualification for in vitro generated plantlets to get themselves eligible for further life in normal growth media under semi protected and open conditions. In the present study, half MS media coupled with $0.5 \mathrm{mg} \mathrm{l}^{-1}$ IBA $\left(\mathrm{T}_{1}\right), 1.0 \mathrm{mg} \mathrm{l}^{-1}$ IBA $\left(\mathrm{T}_{2}\right)$ and $0.5 \mathrm{mg}^{-1} \mathrm{NAA}\left(\mathrm{T}_{3}\right)$ were found to be superior performers for the number of shoots producing roots, rooting percentage, number of roots and girth of roots. Healthy white colour of roots was observed on the cultures rooted from $0.5 \mathrm{mg} \mathrm{l}^{-1}$ IBA $\left(\mathrm{T}_{1}\right), 1.0 \mathrm{mg} \mathrm{l}^{-1}$ IBA $\left(T_{2}\right)$ as compared to other growth regulators.

In sweet potato, Parvin et al., (2018) the maximum root initiation percentage (94.12), the minimum days for root initiation (6.00), the highest number of root/plantlet (9.33) and the maximum root length $(11.13 \mathrm{~cm})$ was found in the MS medium supplemented with IBA $0.5 \mathrm{mg} \mathrm{l}^{-1}+$ NAA $0.1 \mathrm{mg} \mathrm{l}^{-1}$. This result was also supported by findings of made by Ashrafuzzaman et al., (2009).

The probable reason for the superior treatments as above might be that IBA and / or NAA at the above concentrations accelerated more cell division and cell elongation of root than other treatments thus causing more number of roots per plantlet. Some concentrations of IAA produced very less number of roots as compared to IBA at the same strength. The reduced rooting may be due to the imbalance between the endogeneous rooting auxin and exogeneous auxins (Ghanthikumar et al., 2013 and Ani Rani et al., 2019). Culture media supplemented with IBA alone responded well as compared to media fortified with other synthetic auxins (NAA) even in higher concentrations. Kurmi et al., (2011) suggested that IBA promotes in vitro rooting of shootlets. Auxins promoted adventitious root 
development on intact plants as well as excised stems. Of these, IBA was the most effective than any other synthetic auxins in most of the cases, apparently because it is not destroyed by IAA oxidase or other enzymes and therefore persists longer. These facts are confirmed by the results obtained from the present study.

\section{References}

Ani Rani, B, J. Anbumalarmathi, J. and Sharmili. S.A. 2019. In vitro propagation of coccinia indica (L.) Voigt. From intermodal segments. Indian Journal of Agriculture Research. 53(2): 202-07.

Ashrafuzzaman, F, Hossain, M, Ismail, M.R, Shahidul, M, Haque, M, Shahidullah, S. M. and Shahin, U. Z. 2009. Regeneration potential of seedling explants of Ipomoea batatas L. Journal of Applied Horticulture 3:17-22.

Ghanthikumar, S, Arulanandam, L.J.P. and Henry, J.L. 2013. Micropropagation of Coccinia indica Wight \& Arn.- A medicinal plant. International Journal of Applied Biology Research.18: 1-4.

Kurmi, U.S, Sharma, D.K, Tripathi, M.K, Tiwari, R, Baghel, B.S. and Tiwari, S. 2011. Plant regeneration of Vitis vinifera (L) via direct and indirect organogenesis from cultured nodal segments. Journal of Agricultural Technology. 7(3): 721-37.

Parvin, J, Robbani, M, Hasan, Md.F. and Farhana, H. 2018. Standardization of plant growth regulators for successful tissueculture of sweet potato. Journal of Bangladesh Agricultural University. 16(2): 178-81.

\section{How to cite this article:}

Mohammad Amin, A .V. D. Dorajee Rao, K. Ravindra Kumar and Salomi suneetha, D. R. 2020. Effect of invitro Rooting in Coccinia grandis (L.) through Nodal Segments. Int.J.Curr.Microbiol.App.Sci. 9(07): 2266-2272. doi: https://doi.org/10.20546/ijcmas.2020.907.264 